\title{
Climatic and biological forcing of the vertical flux of biogenic particles under seasonal Arctic sea ice
}

\author{
Martin Fortier $^{1, *}$, Louis Fortier ${ }^{1}$, Christine Michel ${ }^{2}$, Louis Legendre ${ }^{3}$ \\ ${ }^{1}$ GIROQ, Département de Biologie, Université Laval, Québec, Québec G1K 7P4, Canada \\ ${ }^{2}$ Department of Fisheries and Oceans, Freshwater Institute, 501 University Crescent, Winnipeg, Manitoba R3T 2N6, Canada \\ ${ }^{3}$ Station Zoologique, BP28, 06234 Villefranche-sur-Mer Cedex, France
}

\begin{abstract}
Ice algae, phytoplankton, zooplankton and the vertical fluxes of chloropigments and particulate organic carbon (POC) were monitored from May to June/July of 1992, 1994 and 1995 under the ice of Barrow Strait (Canadian Arctic Archipelago). Large interannual differences in the timing, magnitude and nature of vertical fluxes were driven by meteorological events that controlled snow cover and by differences in zooplankton assemblages. In 1992, ice algae released from the ice matrix were intensely recycled by the exceptionally abundant calanoid Pseudocalanus acuspes. The persistent snow cover delayed the phytoplankton bloom until after the ice break-up in July. Ice algae were abruptly released and sank rapidly to depth following early rain in late May 1994 and a heatwave in early June 1995. In both years, the early removal of snow triggered an under-ice phytoplankton bloom and strong downward fluxes of POC and chloropigments $\left(13.7 \mathrm{gC} \mathrm{m}^{-2}, 381 \mathrm{mg}\right.$ chloropigments $\mathrm{m}^{-2}$ in 1994). In the absence of nutrient limitation, under-ice fluxes represented a net addition to the annual flux of POC. The analysis of local climate from 1950 to 1995 suggests that strong and early under-ice fluxes of biogenic carbon in spring may become more frequent under the climatic conditions anticipated by general circulation models.
\end{abstract}

KEY WORDS: Sea ice $\cdot$ Carbon flux $\cdot$ Climate forcing $\cdot$ Copepod grazing $\cdot$ Arctic

\section{INTRODUCTION}

The sinking to depth of particulate organic matter produced by photosynthesis in the surface layer of the oceans is the main source of food for benthic communities (e.g. Grebmeier \& Barry 1991), and may represent a significant sink for atmospheric $\mathrm{CO}_{2}$ (e.g. Emerson et al. 1997). Organic particles are often modified during their transit through the water column (e.g. Boyd \& Newton 1995), and the vertical flux of organic matter is made up of a variable combination of ungrazed algal cells, organic aggregates and fast-sinking zooplankton faecal pellets (e.g. Fortier et al. 1994).

In the marginal seas of the Arctic Ocean, photosynthesis is constrained by the strong seasonality in light

*E-mail: martin.fortier@giroq.ulaval.ca and ice cover. In early spring, light attenuation by the snow-covered ice sheet inhibits phytoplankton growth. Microalgal production starts with the development of ice algae in the bottom centimetres of the ice in response to the vernal increase in irradiance (Horner 1985, Cota et al. 1991, Horner et al. 1992). In early summer, the final sloughing of ice algae into the underlying water column coincides with the increase in under-ice irradiance that follows snowmelt (Horner 1985, Cota et al. 1991). The haline stratification and increased irradiance resulting from ice melt often trigger a phytoplankton bloom in the weeks after the ice break-up (e.g. Horner 1985), but under-ice phytoplankton blooms have been reported (Legendre et al. 1981, Fukuchi et al. 1989, Strass \& Nöthig 1996).

Some studies of the under-ice particle flux have suggested that most of the ice algae sink rapidly to the benthos, contributing little to the pelagic ecosystem 
(e.g. Apollonio 1965, Anning 1989). Others have shown that the newly released ice algae can remain in the surface layer long enough for most of the production to be channelled to pelagic grazers (Carey 1987, Tremblay et al. 1989, Michel et al. 1996). Studies of the vertical flux of particulate matter in different years in Barrow Strait, suggest strong interannual variability in the relative importance of grazing and direct sinking as export pathways of primary production under the ice (Anning 1989, Michel et al. 1996). In Barrow Strait, copepods largely dominate the biomass of grazers and are responsible for most of the trophic flux of carbon between primary producers and vertebrates in the pelagic ecosystem (Conover et al. 1991, Welch et al. 1992, Fortier 1999).

Under a scenario of doubled atmospheric $\mathrm{CO}_{2}$ concentration, springtime air temperatures over the Canadian Archipelago are expected to rise by 3 to $5^{\circ} \mathrm{C}$ during the next century (Maxwell 1997). Such warming would strongly affect ice and snow cover dynamics (Wadhams 1990), hastening snowmelt by several weeks and even months (Woo 1990). In the present study, we monitored ice algae, phytoplankton, zooplankton and the vertical fluxes of chloropigments and particulate organic carbon, in relation to snow and sea ice thickness during the spring and early summer of 1992, 1994 and 1995 in Barrow Strait. To help assess the potential impact of future changes in snow and ice cover dynamics on carbon cycling in Arctic waters, we examined how present interannual variability in the meteorological forcing of microalgal blooms and in the abundance of copepod herbivores affect pigment and carbon fluxes. The effects of ice cover and nutrient supplies on the timing, intensity and duration of microalgal blooms and on the reproduction of copepods are discussed in (Fortier 1999).

\section{MATERIALS AND METHODS}

Study area. Barrow Strait is a shallow strait (150 to $200 \mathrm{~m}$ ) in the centre of the Northwest Passage between Viscount Melville Sound to the West and Lancaster Sound to the East (Fig. 1). The area is typically covered by ice from October to July, with maximum ice thickness $(\sim 2 \mathrm{~m})$ and heaviest snow cover in May. In the $3 \mathrm{yr}$ studied, the ice edge of the polynya at the entrance of Lancaster Sound was located at its usual position around the tip of Brodeur Peninsula, over $200 \mathrm{~km}$ from our study area. At this latitude, $24 \mathrm{~h}$ darkness prevails from November to February and midnight sun from late April to mid-August. Because of a moratorium on scientific activities in Resolute Passage imposed by the Resolute Bay Hamlet starting in 1994, our sampling site had to be moved from the original site of 1992, but

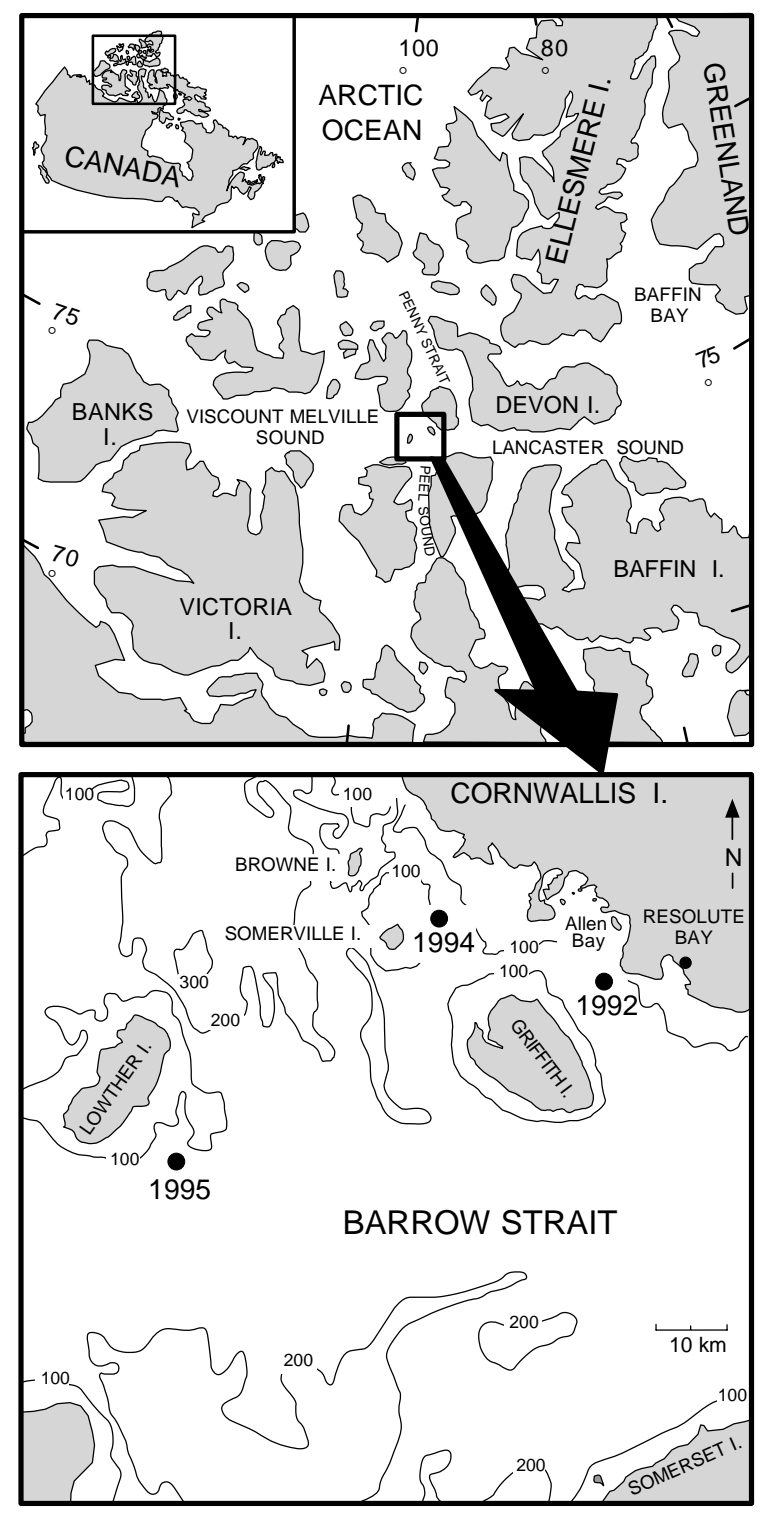

Fig. 1. Map of Canadian Arctic Archipelago showing location of the sampling area (top) and positions of the sampling stations in Barrow Strait (bottom). Isobaths are in metres

always remained on the first-year ice of Barrow Strait in water depths of $135 \mathrm{~m}$ (1992), $125 \mathrm{~m}$ (1994) and $150 \mathrm{~m}$ (1995).

Circulation and the origin of water masses in the study area have been studied by Prinsenberg \& Bennett (1987). Arctic surface water from the Canada Basin enters Barrow Strait from the south through Peel Sound (around Victoria and Banks Islands), from the west through Viscount Melville Sound, and from the north through Penny Strait. Surface waters entering from the west and south have salinity values between 31.5 and 32.5 , which are typical of surface waters in 
the western Archipelago (Prinsenberg \& Bennett 1987). Because of turbulent mixing with subsurface water, surface waters entering from the north have a higher salinity (>32.8) than water from the west and south. This saltier water comes down along both sides of Cornwallis Island and was found in 1982 along the southwestern shore of the island (Prinsenberg \& Bennett 1987). Consistent with this description, salinity values from 32.7 to 33.5 , typical of northern waters, were recorded at our station near SW Cornwallis Island in 1992, while lower values (31.0 to 32.6) typical of western and southern waters were recorded near Somerville Island in 1994 and east of Lowther Island in 1995 (Fortier 1999).

Sampling and analysis. Sampling was conducted on sea ice in and around a heated tent that housed a field laboratory. The ice stations were reached by snowmobile or helicopter. In 1992, sampling took place from 29 April until 24 June. In 1994, we sampled from 29 April until the ice break-up on 11 July, when the camp drifted for $3 \mathrm{~d}$, enabling us to record under-ice sedimentation during the break-up. Ice break-up was late in 1995, allowing us to sample on the ice from 15 May until 11 July. Weather permitting, physical and biological variables were sampled at intervals of about 4 d. Sampling was deferred between 16 June and 1 July 1995 because of fog, which prevented flying.

In 1994 and 1995, incident and underwater photosynthetically active radiation (PAR) were averaged every 15 min until ice break-up using $2 \pi$ Li-Cor sensors (LI-COR, Lincoln, NE) mounted $1 \mathrm{~m}$ above (LI190SA) and $1 \mathrm{~m}$ below (LI-190WA) the ice cover. In 1992, PAR at the ice-water interface $\left(I_{\mathrm{w}}\right)$ was predicted using the model and parameter values from Smith et al. (1988): $\ln \left(I_{\mathrm{w}} / I^{\prime}\right)=-a-c-k_{\mathrm{i}} Z_{\mathrm{i}}-k_{\mathrm{s}} Z_{\mathrm{s}}-k_{\mathrm{chl}}[\mathrm{chl}]$, where $I^{\prime}$ is the incident PAR estimated as $1 / 2$ the total downwelling solar radiation measured in Resolute Bay; $a$ is a parameter for reflection from bare ice; $C$ is a parameter for extra reflection from snow; $Z_{\mathrm{i}}$ and $Z_{\mathrm{s}}$ are ice and snow thickness $(\mathrm{m}) ; k_{\mathrm{i}}$ and $k_{\mathrm{s}}$ are the diffuse attenuation coefficients for ice and snow $\left(\mathrm{m}^{-1}\right) ; k_{\mathrm{chl}}$ is the mean spectral extinction coefficient for chlorophyll $\left(\mathrm{m}^{2} \mathrm{mg}^{-1}\right)$ and [chl] is the areal concentration of chlorophyll a $\left(\mathrm{mg} \mathrm{m}^{-2}\right)$ in the ice bottom. The values predicted by the model were well correlated with the underwater PAR measured in 1994 and $1995\left(r^{2}=0.88\right.$, $\mathrm{n}=106$ ). Daily global irradiance, snow depth, precipitation and air temperature for the 3 sampling years and climate records for the period 1950 to 1995 were provided by the Meteorological Service of Canada in Resolute Bay.

To determine the biomass of ice algae, 3 ice cores were retrieved from each of 2 to 3 different snow depths around the sampling site using a SIPRE ice corer $(7.62 \mathrm{~cm}$ diam.). For each snow depth, the bottom
$4 \mathrm{~cm}(1992)$ or $10 \mathrm{~cm}(1994,1995)$ of the 3 cores were melted in a dark bottle. Water-column microalgae were sampled at 5 depths $(0.5,2.5,5,7.5,15 \mathrm{~m})$ in 1992 and 9 depths $(0,2.5,5,7.5,15,30,60,90 \mathrm{~m}$, bottom) in 1994 and 1995, using 51 Go-Flow or Niskin bottles. Duplicate subsamples of each ice algae or phytoplankton sample was filtered on Whatman GF/F filters for the fluorometric determination of chlorophyll $a(\mathrm{chl} \mathrm{a})$ and phaeopigment (phaeo) concentrations (Model 112, Turner Designs, Sunnyvale, CA) after extraction in $10 \mathrm{ml}$ of $90 \%$ acetone for $24 \mathrm{~h}$ in the dark at $4^{\circ} \mathrm{C}$. A subsample was also filtered on pre-combusted GF/F filters $\left(450^{\circ} \mathrm{C}\right.$ for $\left.24 \mathrm{~h}\right)$ and kept frozen for the later determination of particulate organic carbon (POC) on a Model 240 CHN analyzer (Perkin Elmer, Wellesly, MA). In 1994 and 1995, POC was determined for a subset of samples in the 0 to $30 \mathrm{~m}$ layer.

The vertical flux of particles under the ice was measured at intervals of 2 to $4 \mathrm{~d}$ (1 interval of $16 \mathrm{~d}$ in 1995). Sediment traps made of 1 (1992) or $2(1994,1995)$ PVC cylinders with an aspect ratio of 1:10 (10 cm diam. in 1992 and $7.56 \mathrm{~cm}$ diam. in 1994 and 1995) were moored at $0.5,2.5$ and $15 \mathrm{~m}$ below the ice bottom in 1992 and 2.5, 30 and $90 \mathrm{~m}$ in 1994 and 1995. The traps were filled with filtered sea water supplemented (1992) or not supplemented $(1994,1995)$ with brine before deployment under the ice. No poison or preservative was added. Upon retrieval, the trap content was gently transferred into an 81 (1992) or 4 l (1994, 1995) isothermal container. The traps were then washed, filled, and immediately re-deployed. Subsamples from the trap samples were analyzed for pigments and POC as above. The POC values missing for some dates ( 3 in 1994 and 2 in 1995) were interpolated by multiplying the chloropigment ( $\mathrm{chl} a+$ phaeo) value by the average $\mathrm{C}$ :chloropigment ratio for the samples collected immediately before and after.

In the present study, the sum of chloropigments, after correction of phaeopigment concentrations for destruction into colourless compounds (see below), was used as an index of particulate matter of microalgal origin in the water column and the traps. Estimates of pigment destruction by copepods range from 0 (Pasternak \& Drits 1988) to nearly 100\% (Conover et al. 1986a), with most studies suggesting values between 10 and $35 \%$ (e.g. Dagg \& Walser 1987). In icecovered Hudson Bay, Pseudocalanus sp. and Calanus glacialis, which are the 2 dominant genera in the under-ice copepod assemblage of Barrow Strait, on average destroyed $32 \%$ of the chloropigments they ingested in feeding experiments (Tremblay et al. 1989). The latter value was used to correct phaeopigment concentrations in the water column and the traps. Phaeopigments concentrations in the ice were not corrected for degradation. 
In 1994 and 1995, the content of 1 trap from each depth was concentrated and preserved in $4 \%$ formalin for later analysis of faecal pellets. A subsample representing at least $10 \%$ of the trap content was examined at a magnification of $100 \times$ using an image-analysis system. The lengths and widths of faecal pellets were measured, and pellet volumes were estimated based on their shape (cylindrical or ellipsoidal). The carbon content of faeces was calculated by multiplying the pellet volume by $0.042 \mathrm{mg} \mathrm{C} \mathrm{mm}^{-3}$ for cylindrical copepod pellets and $0.057 \mathrm{mg} \mathrm{C} \mathrm{mm}^{-3}$ for ellipsoidal appendicularian pellets (González et al. 1994). Faecal pellet analyses methodology differed in 1992 (C.M. unpubl. data), and data for that year are not presented.

Zooplankton were collected by towing a $50 \mathrm{~cm}$ diameter standard ring net (64 $\mu \mathrm{m}$ mesh) equipped with a TSK flowmeter from bottom to surface. Samples were preserved in $4 \%$ formalin. In the laboratory, post-naupliar copepods were identified to species and copepodite stage. The total biomass of each calanoid species was calculated by summing for all stages the product of the abundance of each stage by its mass (dry weight) as given by Uye (1982) and Conover \& Huntley (1991).

\section{RESULTS}

\section{Seasonal development of particulate matter in the ice and the water column}

Meteorological events such as rain and warm air temperature that affect snow thickness, ice melt and underwater irradiance, caused large interannual variations in the production and release of ice algae and in the timing of under-ice phytoplankton blooms. These interannual differences, which are detailed elsewhere (Fortier 1999), are summarised here with emphasis on the concentration and quality of chloropigments and POC in the water column and in sediment traps.

The spring of 1992 was characterised by heavy snowfalls that alternated with 2 periods of partial snowmelt (10 to 15 May, 25 May to 10 June) and a final snowmelt (19 June to 1 July) (Fig. 2A). The thick snow cover and a relatively high ice-algae biomass persisted until the end of sampling on 24 June (Fig. 2A, B). Chl a accounted for 75 to $100 \%$ of the ice chloropigments until the beginning of the final snowmelt in late June, when this percentage dropped to $50 \%$ (Fig. 2C). The 3 snowmelt events were closely followed by the input of ice algae into the water column (Fig. 2D). The newlyreleased algae sometimes accumulated into lumps immediately under the ice cover, resulting in very high suspended biomasses (>80 $\mathrm{mg}$ chloropigment $\mathrm{m}^{-3}$ ) at $0.5 \mathrm{~m}$. This explains the peaks in areal concentrations of chloropigments for the 0 to $1 \mathrm{~m}$ layer on 7 and 24 June (Fig. 2D). There was no evidence of an under-ice phytoplankton bloom. Relative to other years, the percent contribution of chl a in water-column chloropigments was remarkably low (10 to $65 \%$ ) at all times in 1992 (Fig. 2E, J, O).

Ice algae were less abundant in 1994 and 1995 than in 1992. In 1994, the final release from the ice matrix coincided with heavy rain that melted the snow cover (Fig. 2F, G). In 1995, the ice algae were released on the days following a heatwave that quickly melted the thick snow cover (Fig. 2K, L). In both years, the percent contribution of chl a in bottom-ice chloropigments was always $>75 \%$, except at the time of ice break-up in 1994 (Fig. 2H, M). In 1994 and 1995, the final release of ice algae coincided with an increase in water-column chloropigments (Fig. 2I, N). In both years, the increase in PAR resulting from the reduction of the snow cover was followed about $2 \mathrm{wk}$ later by an under-ice phytoplankton bloom. The chl a/chloropigment ratio in the water column was high (50 to 95\%) relative to 1992 (10 to $65 \%$ ), and increased to $>90 \%$ in the surface layer $(0$ to $15 \mathrm{~m})$ during the under-ice phytoplankton bloom (Fig. 2J, O). The ratio decreased with increasing depth, on average by $16.4 \%$ (1994) and $9.1 \%$ (1995) between the 0 to $15 \mathrm{~m}$ and 30 to $90 \mathrm{~m}$ layers.

In all $3 \mathrm{yr}$, pennate diatoms of the genera Nitzschia, Fragilariopsis and Navicula dominated the algal biomass in the ice and the water column (1992: Michel et al. 1996; 1994 and 1995: Fortier unpubl. data). Nitzschia spp. and Fragilariopsis spp. contributed the most to the under-ice phytoplankton blooms of 1994 and 1995 (Fortier unpubl. data).

Concentrations of suspended POC in the surface layer (0 to $15 \mathrm{~m}$ ) remained low during the 1992 sampling season, except for peaks that corresponded to the last 2 melt events during the period of release of ice algae (Fig. 3A). POC in the water column was low during the production and release of ice algae in 1994 and 1995, and increased with the development of the under-ice phytoplankton bloom in late June 1994 and early July 1995 (Fig. 3B, C). The POC/chloropigment ratio in the 0 to $15 \mathrm{~m}$ layer was high in 1992 relative to 1994 and 1995 (Fig. 3D-F). In 1994 and 1995, the ratio remained relatively high until the release of ice algae, and decreased with the development of the phytoplankton bloom (Fig. 3E, F).

\section{Species composition and seasonal abundance of copepods}

In the 3 yr sampled, copepods dominated the zooplankton, with the calanoids Microcalanus pygmaeus, Pseudocalanus acuspes, Metridia longa, Calanus gla- 

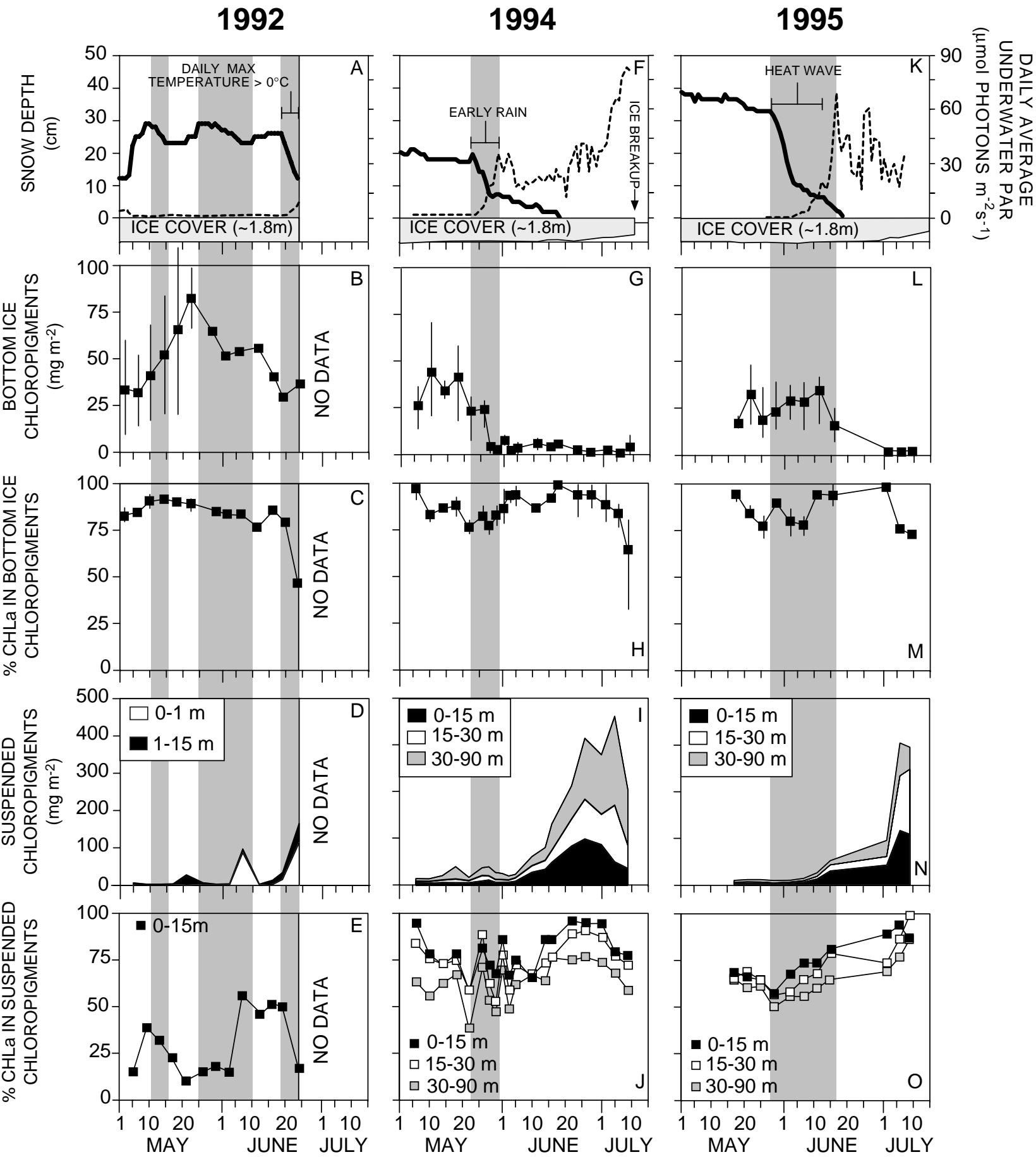

Fig. 2. Barrow Strait in spring and early summer. Interannual comparison of snow thickness, ice cover and daily average underwater PAR $(A, F, K)$, average $( \pm S D)$ areal concentration of chloropigments (chl a + phaeo) in the bottom ice $(B, G, L)$, percent contribution of chl a to total chloropigments in the bottom ice $(\mathrm{C}, \mathrm{H}, \mathrm{M})$, areal concentration of chloropigments in different depth strata of the water column (D, I, N), and percent contribution of chl a to total chloropigments in the different depth strata (E, J, O).

Shaded vertical bands correspond to periods of snowmelt

cialis, C. hyperboreus, and and the small cyclopoids Oncaea borealis and Oithona similis making up $98 \%$ of the copepod assemblage by number (Fortier et al.
1995, Fortier 1999). The most striking interannual difference in the copepod assemblage was the exceptional abundance of $P$. acuspes $\mathrm{C} 4, \mathrm{C} 5$ and adults in 
1992

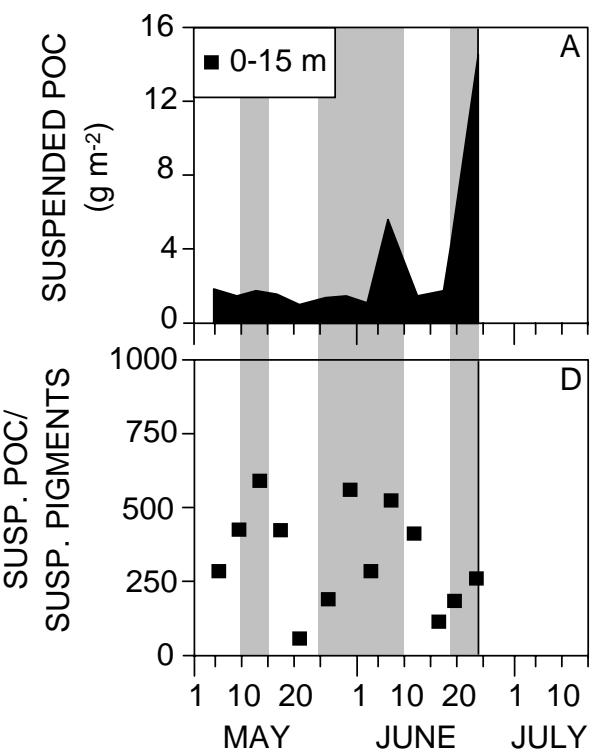

1994
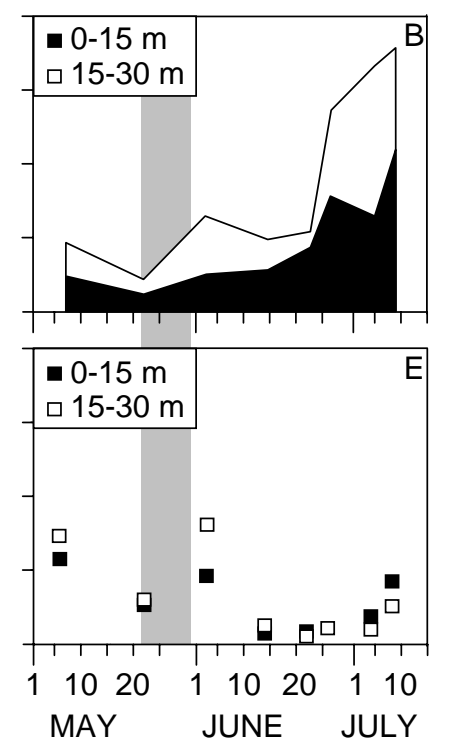

1995
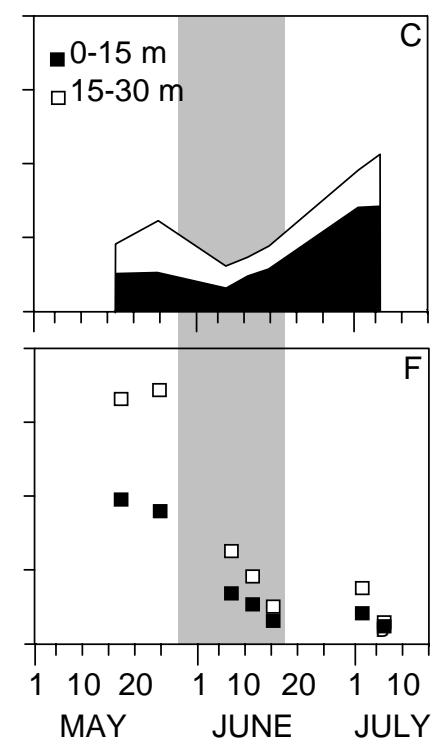

Fig. 3. Interannual comparison of concentration of particulate organic carbon (POC) (A, B, C) and POC/total chloropigments (chl $a$ and phaeo) ratio (D, E, F) in 0 to 15 and 15 to $30 \mathrm{~m}$ depth strata under the ice of Barrow Strait in 1992,1994 and 1995. Shaded vertical bands correspond to periods of snowmelt
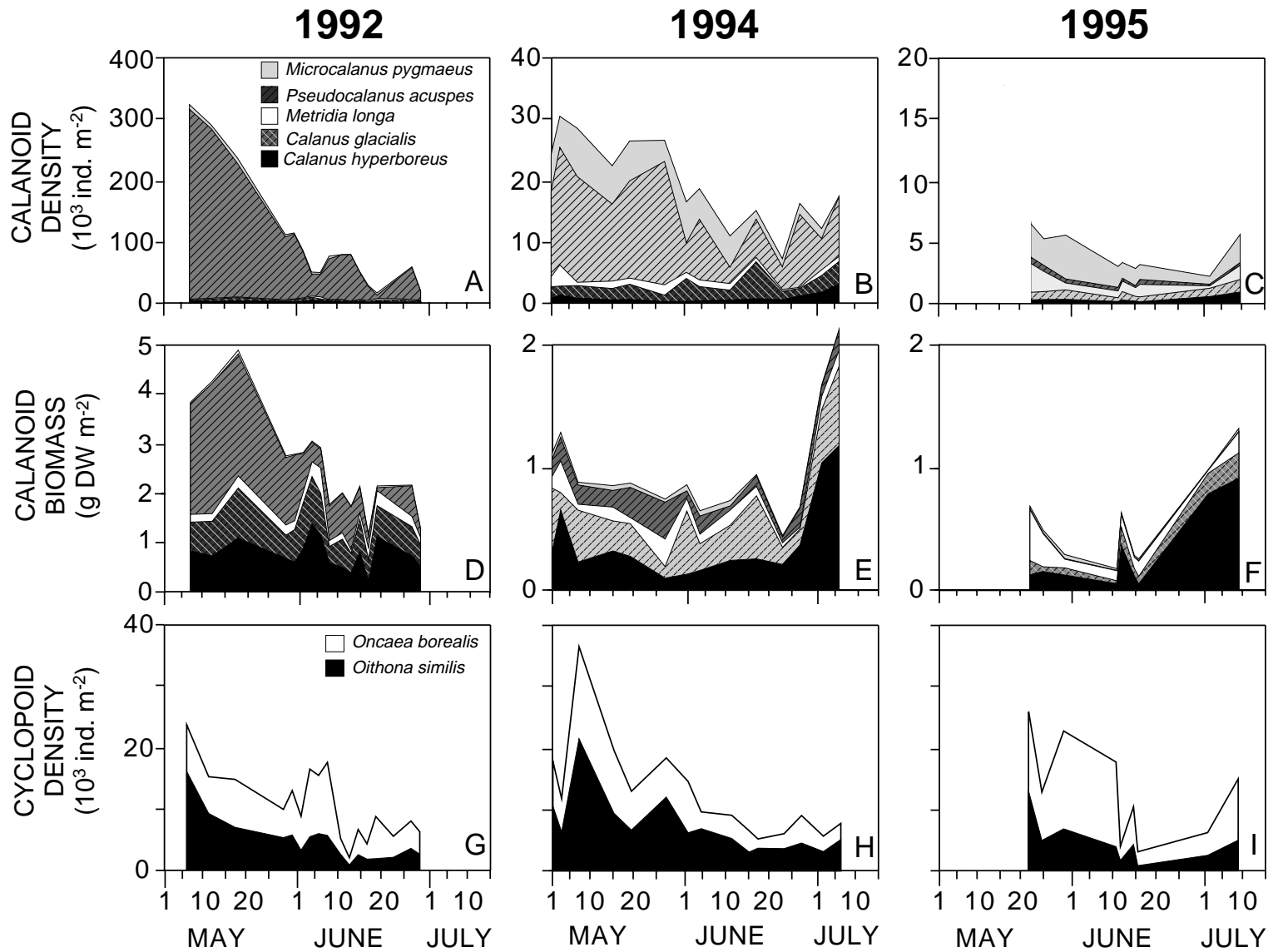

Fig. 4. Interannual comparison of areal density (A, B, C) and biomass (D, E, F) of the major calanoid copepods and areal density of cyclopoid copepods (G, H, I) under the ice of Barrow Strait in 1992, 1994 and 1995. Note changes of scales among years for calanoid copepod density and biomass 
1992

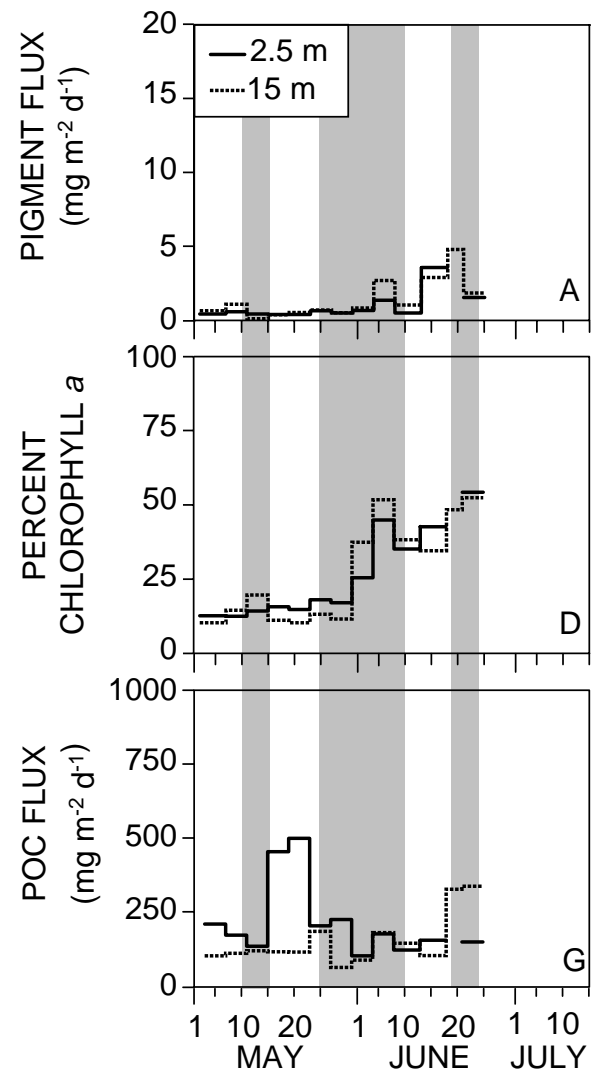

1994
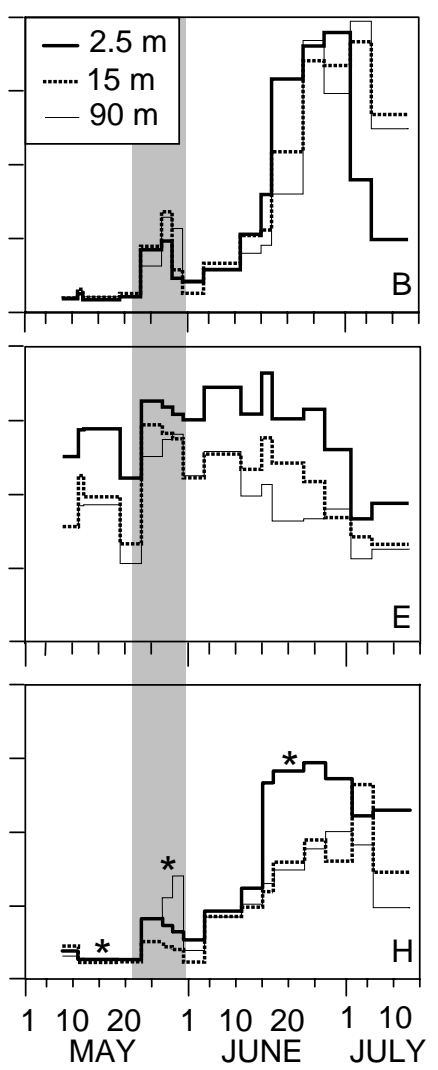

1995

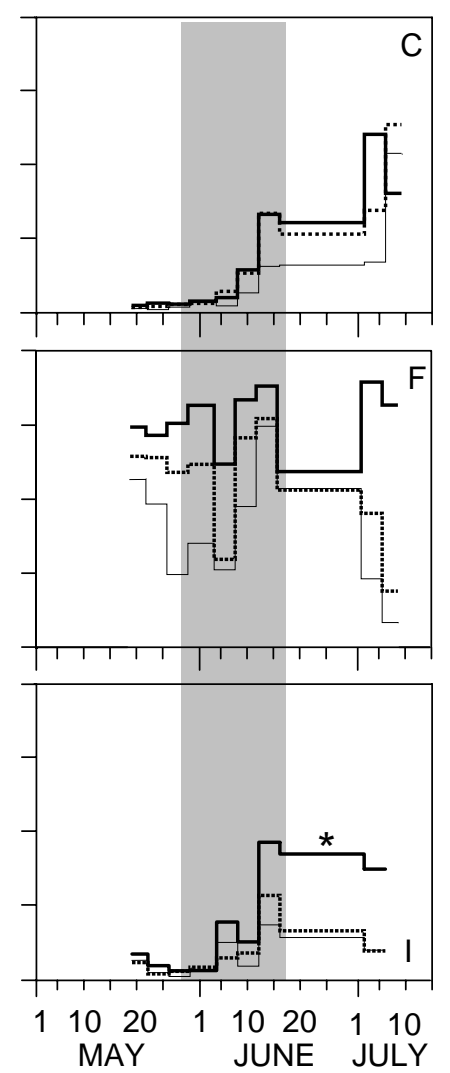

Fig. 5. Interannual comparison of total chloropigment flux (chl $a+$ phaeo) $(A, B, C)$, percent contribution of chl $a$ to total chloropigments in sediment traps (D, E, F), and particulate organic carbon (POC) flux (G, H, I) at different depths under the ice of Barrow Strait in 1992, 1994 and 1995. Missing POC data for some trap deployments in 1994 and 1995 (*) were interpolated by multiplying the chloropigment value by the mean $\mathrm{C} /$ chloropigment ratio from the previous and following deployments. Shaded vertical bands correspond to periods of snowmelt

1992 (up to $3 \times 10^{5} \mathrm{~m}^{-2}$ in early May), which resulted in drastic year-to-year variations in the overall number and biomass of calanoids (Fig. 4A-F). P. acuspes averaged 33,17 , and $2 \%$ of the calanoid biomass and 84,37 and $3 \%$ of the total number of copepods (calanoids + cyclopoids) in 1992, 1994 and 1995, respectively. Given their large sizes, M. longa, C. glacialis, and C. hyperboreus represented between $50 \%$ (1992) and nearly $100 \%$ (1995) of the biomass of calanoids. The abundance of cyclopoid copepods varied little between years (Fig. 4G-I).

\section{Vertical fluxes of pigments and particulate organic carbon}

In the 3 sampling years, modest increases in the vertical flux of chloropigments occurred during and immediately after the release of ice algae (Fig. 5A-C). In 1994 and 1995, the main increase in the pigment flux coincided with the under-ice phytoplankton bloom
(Fig. 5B, C). The contribution of chl a to total chloropigment in the traps was low in 1992 (14 to $62 \%$ ) relative to 1994 and 1995 (40 to 95\%) (Fig. 5D-F). This contribution decreased with increasing depth in 1994 and 1995, except during the release of ice algae. In 1995, the recovery of sediment traps deployed on 16 June was delayed until 31 June by adverse weather. The relatively low chloropigment flux and weak contribution of chl a to total chloropigment measured over this period probably resulted from pigment degradation (Fig. 5C, F). The POC flux increased at $15 \mathrm{~m}$ in 1992 during the final melt event, and at all depths during the abrupt ice algal releases of 1994 and 1995 (Fig. 5G-I). A major increase in the POC flux coincided with the under-ice phytoplankton bloom in 1994 and 1995 (Fig. 5H, I). Relative to 1994 and 1995, the pigment and POC fluxes were poorly correlated in 1992 (Fig. 6). In particular, high POC fluxes were recorded from 15 to 23 May, in the absence of any significant pigment flux (Fig. 5A, G). The POC/chloropigment ratio in the traps averaged 541 in 1992 compared to 60 in 1994 and 74 in 


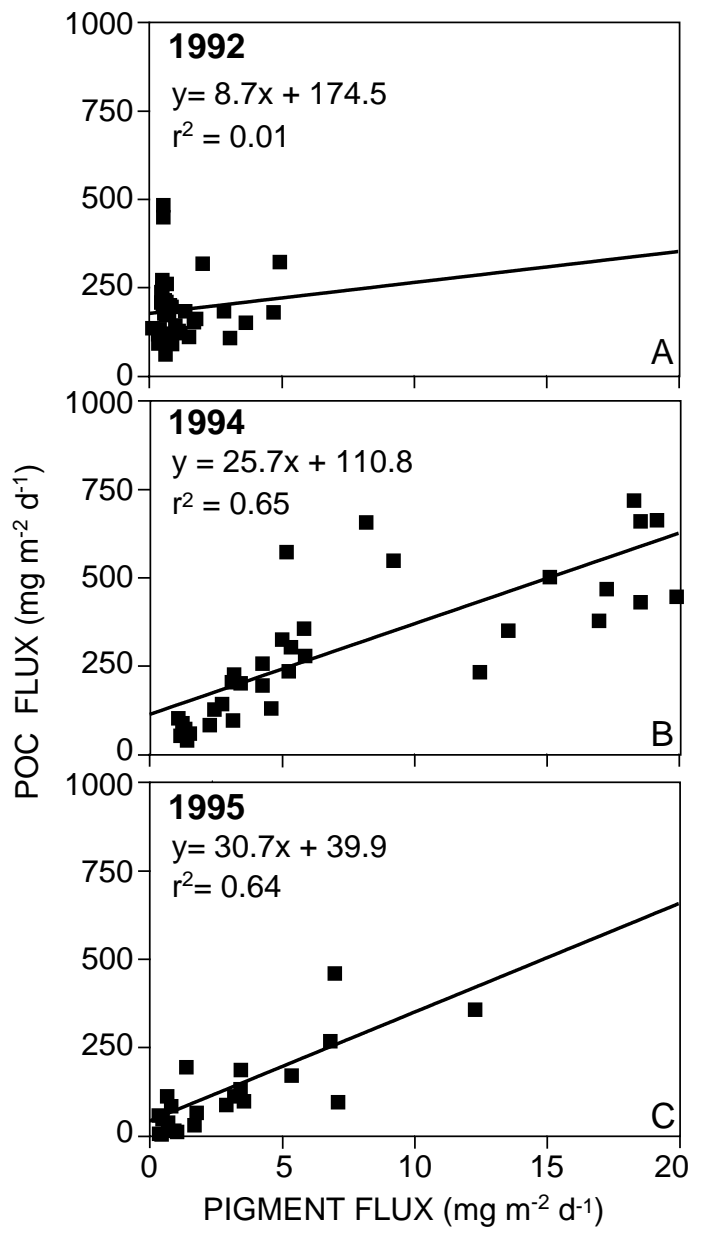

Fig. 6. Vertical flux of particulate organic carbon (POC) in relation to the flux of total chloropigments (chl $a+$ phaeo) under the ice of Barrow Strait from May to July of 1992, 1994 and 1995

1995. The species composition of algal cells in the traps reflected that of the ice and water column with the pennates Nitzschia spp., Fragilariopsis spp. and Navicula spp. dominating the flux (1992: Michel et al. 1996; 1994 and 1995: Fortier unpubl. data).

\section{Export efficiency of chloropigments}

The fraction of the standing stock of chloropigments (ice + water column) that was exported beyond a given depth each day (daily flux in trap $\times 100$ /standing stock above trap) varied among years and over the season (Fig. 7). At any time in 1992, $<7 \%$ of the chloropigments contained in the ice and the 0 to $15 \mathrm{~m}$ layer sank beneath $15 \mathrm{~m}$ daily, this fraction tending to increase during the season (Fig. 7A). The seasonal pattern of chloropigment export was similar in 1994 and 1995: the fraction exported was low initially $(<3 \%)$, in-

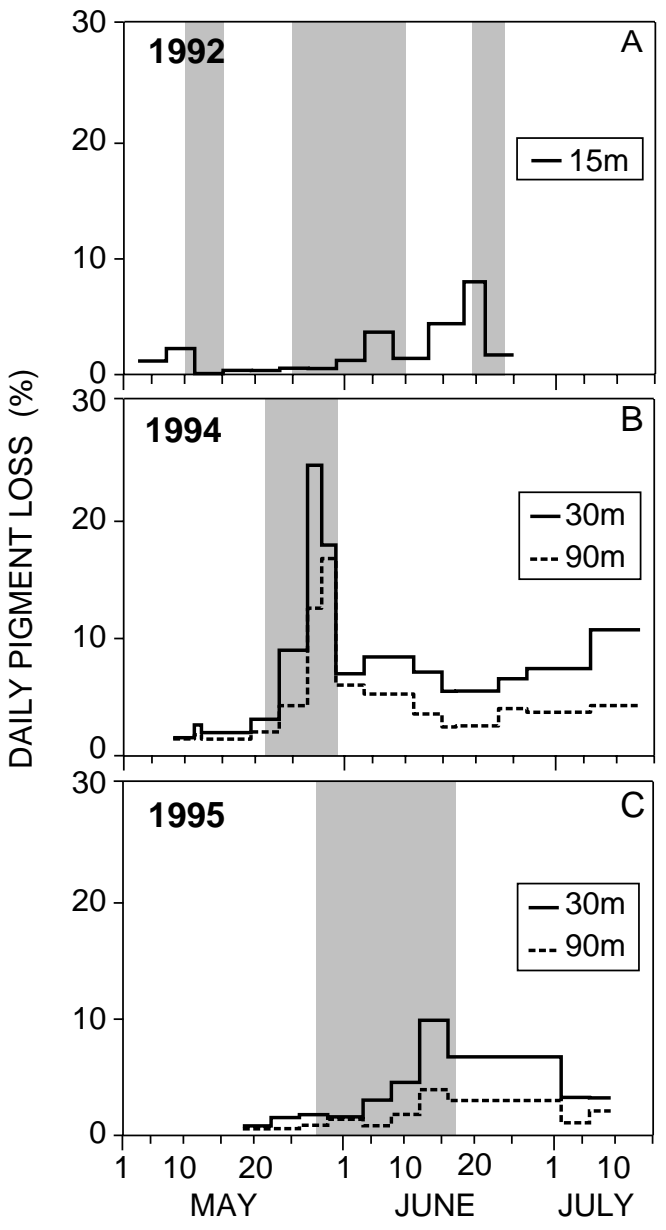

Fig. 7. Seasonal variations in daily percent loss of total chloropigments (daily flux in trap $\times 100$ /standing stock of chl $a+$ phaeo above trap) at different depths under the ice of Barrow Strait in 1992, 1994 and 1995. Shaded vertical bands correspond to periods of snowmelt

creased briefly at or immediately after the release of ice algae (10 to $25 \%$ ), and remained at intermediate values and relatively stable (5 to $10 \%$ ) during the under-ice phytoplankton bloom (Fig. 7B, C). In general, export efficiency decreased with increasing depth and was greater in 1994 than in 1995.

\section{Faecal flux in 1994 and 1995}

When averaged over the sampling season, the sinking flux of faecal matter increased with increasing depth and was ca 4 times higher in 1994 than in 1995 (Table 1). In both years, the identifiable faecal matter collected in the sediment traps consisted primarily of intact or broken cylindrical faecal pellets of calanoid copepods. The contribution of dark, compact, ellipsoidal appendicularian pellets to the total faecal flux 
Table 1. Volume of faecal flux, \% contribution of appendicularian pellets to volume of faecal flux, carbon content of faecal flux taking into account the contribution of copepods and appendicularians according to Gonzalez et al. (1994) (see 'Materials and methods'), and \% contribution of faecal flux to the total POC flux, by depth and year. Data are means (SD) over sampling period

\begin{tabular}{|lccc|}
\hline & Depth (m) & \multicolumn{1}{c|}{1994} & 1995 \\
\hline Faecal flux & 2.5 & $112.2(64.5)$ & $34.6(31.4)$ \\
$\left(\mathrm{mm}^{3} \mathrm{~m}^{-2} \mathrm{~d}^{-1}\right)$ & 30 & $187.8(127.5)$ & $57.7(42.9)$ \\
& 90 & $243.2(107.9)$ & $60.2(30.3)$ \\
\% appendicularian & 2.5 & $0.1(0.3)$ & $3.0(2.7)$ \\
& 30 & $0.6(0.9)$ & $10.4(8.3)$ \\
& 90 & $1.0(1.0)$ & $11.0(7.1)$ \\
Faecal carbon flux & 2.5 & $4.7(2.7)$ & $2.0(1.7)$ \\
(mg m $\left.{ }^{-2} \mathrm{~d}^{-1}\right)$ & 30 & $7.9(5.3)$ & $3.2(2.4)$ \\
& 90 & $10.3(4.6)$ & $3.2(1.4)$ \\
\% of POC flux & 2.5 & $3.2(3.1)$ & $1.3(1.5)$ \\
& 30 & $7.7(9.9)$ & $3.0(1.6)$ \\
& 90 & $6.9(5.4)$ & $6.1(4.7)$ \\
\hline
\end{tabular}

was smaller in 1994 than 1995, and increased with increasing trap depth in both years (Table 1). Averaged over the season, the contribution of faecal matter to the POC flux tended to increase with depth, but did not exceed $8 \%$ (Table 1 ).

In both years and at all depths, the flux of faecal pellets peaked briefly in the days following the final release of ice algae, with a tendency to increase again at the very end of the sampling season in early July (Fig. 8A-F). The faecal fraction of the POC flux was highest at or after the release of ice algae (up to $35 \%$ at $30 \mathrm{~m}$ in 1994), after which it declined as the phytoplankton bloom developed (Fig. 8G, H).

\section{Microalgae biomass, copepods and the vertical flux of particles}

Excluding the very high estimates of microalgae biomass (>50 $\mathrm{mg} \mathrm{m}^{-3}$ ) associated with lumps of floating algae in the 0 to $1 \mathrm{~m}$ layer in 1992, the standing stock of microalgae in the water column above the trap accounted for 64 to $91 \%$ of the seasonal variability in the chloropigment flux at depth $(>15 \mathrm{~m})$ in all $3 \mathrm{yr}$ (Fig. 9, Table 2).

While having little impact on the magnitude of the pigment flux (Table 2), the biomass of calanoid copepods accounted for the largest fraction of the variance in the nature of this flux (Table 3). Calanoid biomass accounted for a significant fraction of the seasonal variance in the chl a:chloropigment ratio of the flux in 1992 and 1994, but not in 1995 when their abundance was low (Table 3). In 1992, the density of Pseudocalanus acuspes accounted for ca $69 \%$ of the seasonal variance in the chl a:chloropigment ratio in the traps at all depths (Table 3 ). No other variable significantly contributed to accounting for seasonal variance in the ratio. In 1994, the biomass of the calanoids Calanus hyperboreus, Metridia longa and, to a lesser extent, $P$. acuspes, was the main determinant of the chl a: chloropigment ratio in the traps (Table 3). In 1995, the standing stock of chloropigments above the trap accounted for between 17 and $45 \%$ of the seasonal variance in the chl a:chloropigment ratio in the traps, but the coefficient of determination was significant only for the $30 \mathrm{~m}$ trap (Table 3 ).

\section{DISCUSSION}

\section{Snow cover and under-ice fluxes of biogenic particles in seasonally ice-covered seas}

Several authors have pointed to the potential (but essentially unknown) importance of chloropigment and POC fluxes taking place between the end of ice algae production and the open-water phytoplankton bloom (Carey 1987, Anning 1989, Tremblay et al. 1989, Michel et al. 1996). Yet, owing to difficult logistics, records of particle fluxes under first-year sea ice seldom extend into the period of advanced melt and ice break-up that may take place weeks after the decline in ice algae biomass. Our results indicate that, depending on snow cover dynamics, these fluxes may be important in some years and negligible in others. In 1992, the persisting snow cover blocked light and the development of phytoplankton under the ice until late June. The ice break-up took place in mid-July within days of our departure, and it is unlikely that any significant under-ice production occurred before the open-water phytoplankton bloom. Hence, most of the flux before the ice break-up in 1992 was fuelled by the production of ice algae, and could not exceed by much the time-integrated $8 \mathrm{gC} \mathrm{m}^{-2}$ (69 mg chloropigments $\mathrm{m}^{-2}$ ) recorded at $15 \mathrm{~m}$. For comparison, from 1984 to 1988, the time-integrated flux of algae carbon until the end of the ice algae production in Barrow Strait ranged from 2 to $4 \mathrm{~g} \mathrm{C} \mathrm{m}^{-2}$ (34 to $83 \mathrm{mg}$ chloropigments $\mathrm{m}^{-2}$ ) (Anning 1989).

In 1994 and 1995, the intense under-ice bloom that followed the early removal of the snow cover and the increase in under-ice irradiance, generated the bulk of the overall flux of particles before the ice break-up. In 1994, $16.7 \mathrm{~g} \mathrm{C} \mathrm{m}^{-2}$ (465 mg chloropigments $\mathrm{m}^{-2}$ ) were exported to depth $(90 \mathrm{~m})$ before the ice break-up, of which $82 \%$ (13.7 $\mathrm{g} \mathrm{C} \mathrm{m}^{-2}$, $381 \mathrm{mg}$ chloropigments $\mathrm{m}^{-2}$ ) resulted primarily from the sinking of relatively pris- 

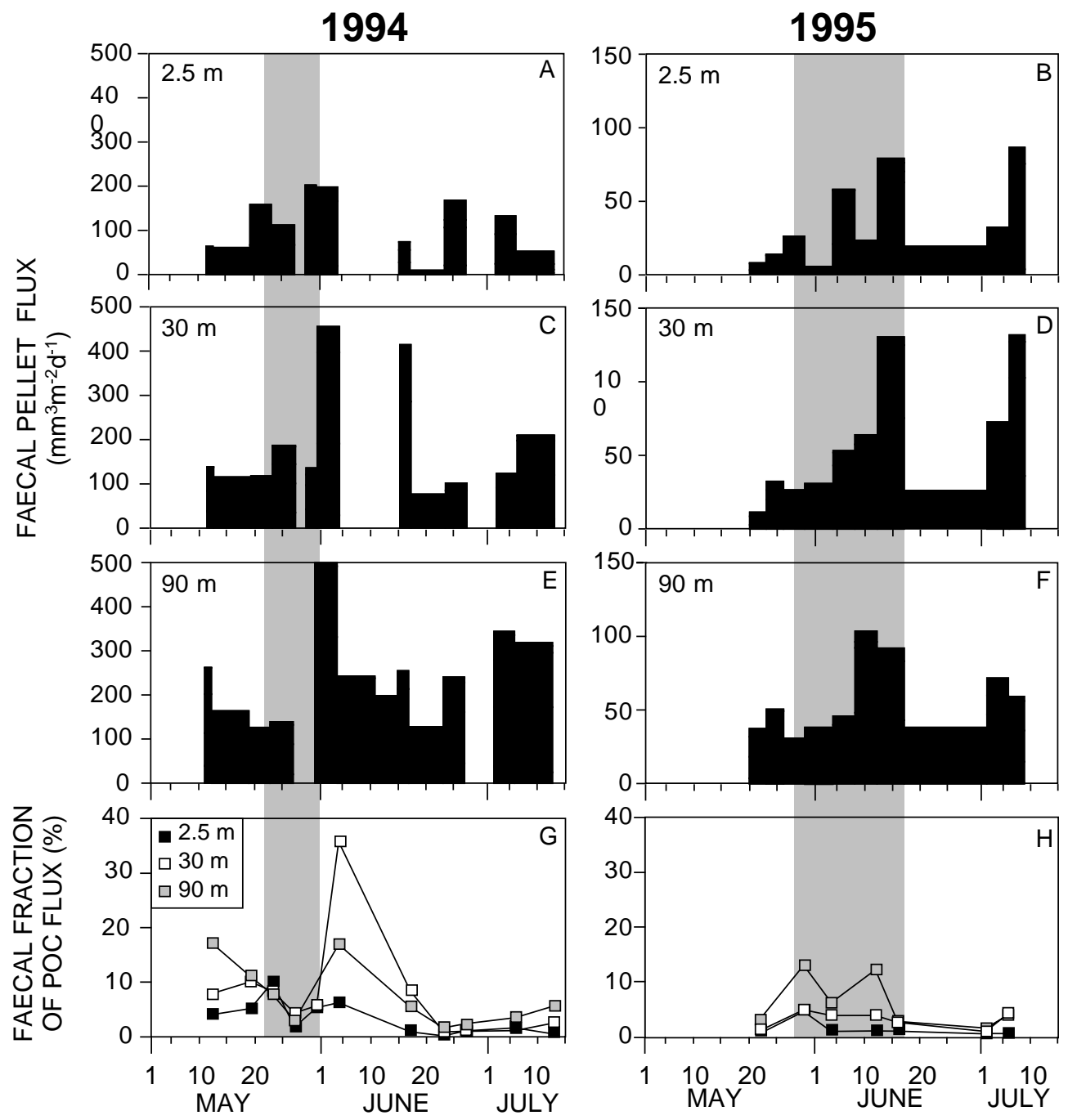

Fig. 8. Seasonal variations in volume of faecal pellet flux (A-F) and fraction of particulate organic carbon (POC) flux contained in faecal pellets $(G, H)$ at different depths under the ice of Barrow Strait in 1994 and 1995. Shaded vertical bands correspond to periods of snowmelt

Table 2. Multiple regressions: percentage $\left(\mathrm{r}^{2}\right)$ of seasonal variance in the magnitude of the chloropigment flux at a given depth accounted for by biomass of chloropigments $\left(\mathrm{mg} \mathrm{m}^{-2}\right)$ above the trap, chlorophyll a:chloropigment ratio in the trap, and biomass (dry wt $\mathrm{m}^{-2}$ ) of different calanoid copepods in the water column in 1992, 1994 and 1995. Bold values correspond to correlation coefficients $(r)$ that are significantly different from zero $(\mathrm{p}<0.05)$; other values are non-significant

\begin{tabular}{|lrrrrrrrrr}
\hline Variable & \multicolumn{3}{c}{1992} & & & \multirow{2}{*}{1994} & & & \multicolumn{2}{c|}{1995} \\
& $0.5 \mathrm{~m}$ & $2.5 \mathrm{~m}$ & $15 \mathrm{~m}$ & $2.5 \mathrm{~m}$ & $30 \mathrm{~m}$ & $90 \mathrm{~m}$ & $2.5 \mathrm{~m}$ & $30 \mathrm{~m}$ & $90 \mathrm{~m}$ \\
\hline Chloropigment biomass above trap & 3.4 & 15.8 & $\mathbf{6 3 . 7}$ & $\mathbf{8 0 . 2}$ & $\mathbf{8 9 . 1}$ & $\mathbf{9 0 . 8}$ & $\mathbf{7 5 . 4}$ & $\mathbf{8 6 . 3}$ & $\mathbf{8 6 . 1}$ \\
Calanus hyperboreus biomass & 6.9 & 7.6 & 3.3 & 0.5 & 2.4 & 0.2 & $\mathbf{1 7 . 0}$ & 2.1 & 0.5 \\
Microcalanus pygmaeus biomass & 6.2 & 3.2 & 0.7 & 4.7 & 0.0 & 0.8 & 0.9 & 0.8 & 0.2 \\
Metridia longa biomass & 2.9 & 7.7 & 1.3 & 0.2 & $\mathbf{5 . 5}$ & 1.9 & 0.0 & 0.4 & 0.0 \\
Pseudocalanus acuspes biomass & 27.9 & 12.5 & 12.4 & 0.6 & 0.5 & 1.1 & 0.1 & 4.1 & 0.6 \\
Calanus glacialis biomass & 5.2 & 5.8 & 0.5 & $\mathbf{4 . 9}$ & 0.0 & 0.9 & 0.1 & 3.8 & 0.2 \\
n (no. of measurements) & 11 & 11 & 11 & 16 & 16 & 16 & 10 & 10 & 10 \\
Total variance accounted for & 52.5 & 52.6 & 81.9 & 91.1 & 97.5 & 95.7 & 93.5 & 97.5 & 87.6 \\
\hline
\end{tabular}




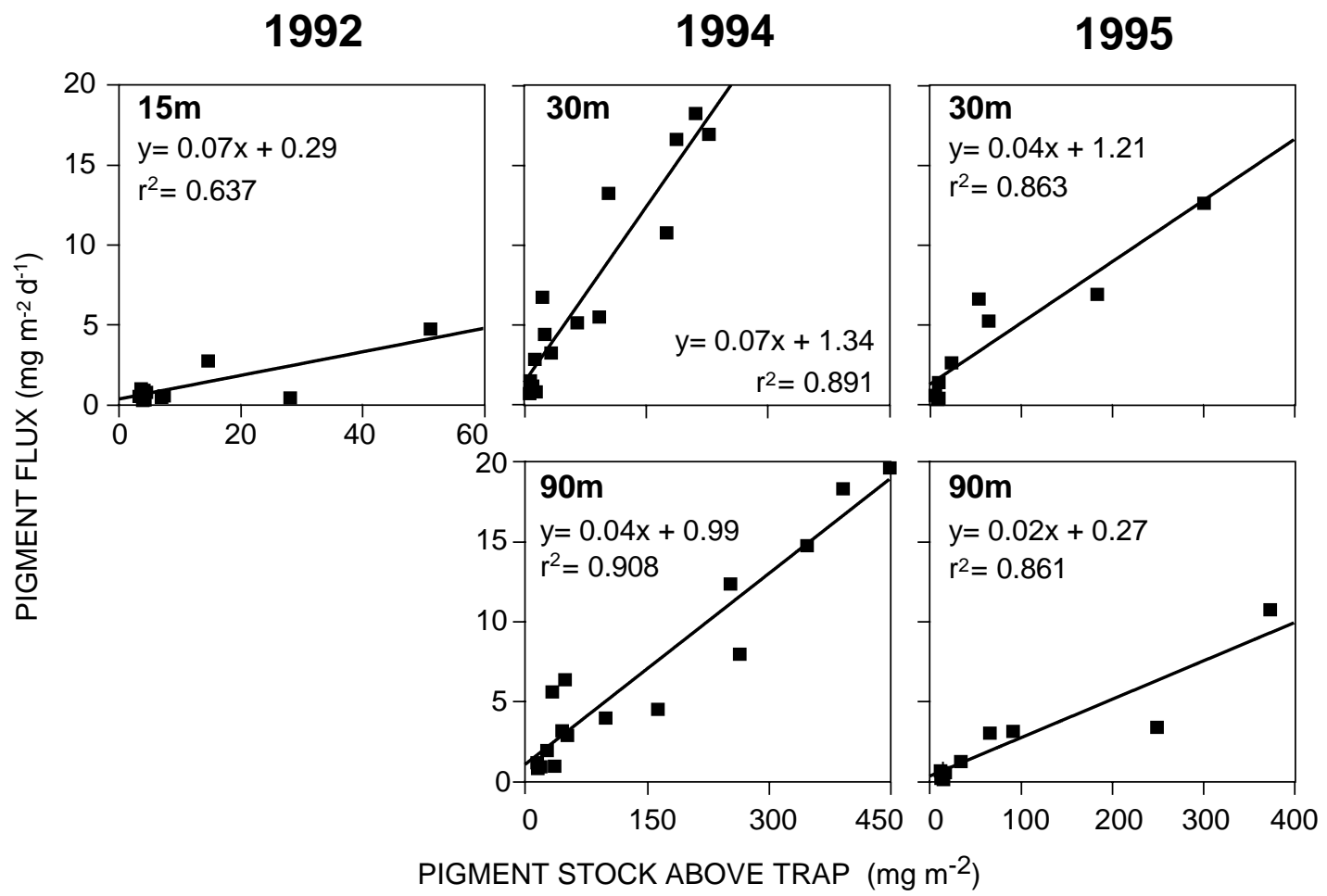

Fig. 9. Vertical flux of total chloropigments ( $\mathrm{chl} a+$ phaeo) in relation to standing stock of total chloropigments above the trap at different depths under the ice of Barrow Strait from May to July of 1992, 1994 and 1995

tine material with a low C:chloropigment ratio (35 to 50) during the under-ice phytoplankton bloom. In 1995, our sampling ended before the end of the underice bloom, when the time-integrated flux had reached $5.5 \mathrm{~g} \mathrm{C} \mathrm{m}^{-2}$ (121 mg chloropigments $\mathrm{m}^{-2}$ ), of which $79 \%$ was ungrazed phytoplankton. In 1983, Anning (1989) recorded an overall flux of $13 \mathrm{~g} \mathrm{C} \mathrm{m}^{-2}$ of algal origin (265 mg chloropigments $\mathrm{m}^{-2}$ ) when traps were accidentally left in place for an additional $3 \mathrm{wk}$ after the release of ice algae. In that year, 96 to $98 \%$ of the accumulated flux of pigments occurred during that additional period of trap deployment, after the final sloughing of ice algae. Anning (1989) mentions that the melt of the snow cover, a necessary condition for an under-ice phytoplankton bloom to develop, had taken place just before the last deployment of the traps. We suspect that the high fluxes of carbon and pigments recorded after the release of ice algae in 1983 resulted from an under-ice phytoplankton bloom, as observed in 1994 and 1995. With values of 500 (1994) and 150 (1995) $\mathrm{mg} \mathrm{C} \mathrm{m} \mathrm{m}^{-2} \mathrm{~d}^{-1}$, maximum daily fluxes of $\mathrm{POC}$ at $90 \mathrm{~m}$ during the under-ice blooms were

Table 3. Multiple regressions: percentage $\left(\mathrm{r}^{2}\right)$ of seasonal variance in chlorophyll a:chloropigment ratio in the traps at a given depth accounted for by different variables in 1992, 1994 and 1995. Bold values as in Table 2

\begin{tabular}{|c|c|c|c|c|c|c|c|c|c|}
\hline \multirow[t]{2}{*}{ Variable } & \multicolumn{3}{|c|}{1992} & \multicolumn{3}{|c|}{1994} & \multicolumn{3}{|c|}{1995} \\
\hline & $0.5 \mathrm{~m}$ & $2.5 \mathrm{~m}$ & $15 \mathrm{~m}$ & $2.5 \mathrm{~m}$ & $30 \mathrm{~m}$ & $90 \mathrm{~m}$ & $2.5 \mathrm{~m}$ & $30 \mathrm{~m}$ & $90 \mathrm{~m}$ \\
\hline Pseudocalanus acuspes biomass & 69.1 & 69.2 & 68.0 & 4.8 & 9.4 & 17.2 & 1.0 & 4.3 & 24.0 \\
\hline Calanus hyperboreus biomass & 7.9 & 0.2 & 1.0 & 57.2 & 48.1 & 35.6 & 1.5 & 5.0 & 2.7 \\
\hline Metridia longa biomass & 1.1 & 7.3 & 0.7 & 4.9 & 15.1 & 27.5 & 1.2 & 0.3 & 10.8 \\
\hline Microcalanus pygmaeus biomass & 0.0 & 1.0 & 1.9 & 0.8 & 0.3 & 1.5 & 32.6 & 30.3 & 20.6 \\
\hline Calanus glacialis biomass & 3.0 & 3.9 & 2.0 & 0.1 & 2.9 & 0.8 & 11.4 & 6.0 & 2.6 \\
\hline Chloropigment biomass above trap & 2.7 & 5.7 & 5.4 & 19.5 & 13.7 & 0.5 & 17.7 & 44.9 & 30.7 \\
\hline n (no. of measurements) & 11 & 11 & 11 & 16 & 16 & 16 & 10 & 10 & 10 \\
\hline Total variance accounted for & 83.8 & 87.3 & 79.0 & 87.3 & 89.5 & 83.1 & 65.4 & 90.8 & 91.4 \\
\hline
\end{tabular}


commensurate with maximum fluxes during the spring bloom in the North Atlantic $\left(305 \mathrm{mg} \mathrm{C} \mathrm{m}^{-2} \mathrm{~d}^{-1}\right.$ : Bender et al. 1992), the Kattegat (up to $700 \mathrm{mgC}$ $\mathrm{m}^{-2} \mathrm{~d}^{-1}$ : Olesen \& Lundsgaard 1995), the North Sea (185 $\mathrm{mg} \mathrm{C} \mathrm{m}^{-2} \mathrm{~d}^{-1}$ ), and in Balsfjord and Malangen fjords in northern Norway $\left(500 \mathrm{mg} \mathrm{C} \mathrm{m}^{-2} \mathrm{~d}^{-1}\right.$ : Wassmann et al. 1996).

Relative to 1994 and 1995, the weak correlation between pigment and POC fluxes, and the higher POC:chloropigment ratio (Figs 5 \& 6), suggested that sources other than microalgal production contributed to the POC flux in 1992. Because sampling-site location changed among years, the water flowing from the north around Cornwallis Island (Prinsenberg \& Bennett 1987) was sampled in 1992, while water from the south or the west was sampled in 1994 and 1995 (see 'Materials and methods: Study area'). While a more complete analysis of the sedimenting material is needed to verify this hypothesis, lithogenic POC from nearby Cornwallis Island could have contributed to the POC flux measured in 1992.

Several authors have concluded that total primary production in Arctic waters is not limited by nitrate depletion because of nitrogen re-mineralisation in the euphotic layer (e.g. Harrison et al. 1982, Harrison \& Platt 1986, Harrison \& Cota 1991, Conover et al. 1999). Temperature and light, rather than nutrients, would limit Arctic phytoplankton growth (Harrison et al. 1982, Rysgaard et al. 1999). Based on the incomplete consumption of nitrates at any time $\left(\mathrm{NO}_{3}+\mathrm{NO}_{2}>2 \mu \mathrm{M}\right)$ and on the partial replenishment of surface nutrients by wind-mixing after the ice break-up, we estimated elsewhere (Fortier 1999) that, in 1994, even new production during the open-water bloom was not limited by prior reduction of nutrients during the under-ice bloom. In the absence of competition for nutrients between the under-ice and open-water blooms, the early flux of particles resulting from the under-ice bloom must represent an extra contribution to the overall annual flux. The actual importance of this additional contribution is difficult to assess since, to our knowledge, the total annual vertical flux of carbon has not been determined in Barrow Strait or elsewhere in the Arctic Archipelago. In sub-arctic Frobisher Bay, Atkinson \& Wacasey (1987) measured an annual vertical flux of $26 \mathrm{~g} \mathrm{C} \mathrm{m}^{-2}$, representing from 31 to $53 \%$ of the range of estimates for total carbon fixed over the year (49 to $84 \mathrm{~g} \mathrm{C} \mathrm{m}^{-2}$ ). For comparison, the $13.7 \mathrm{~g} \mathrm{C} \mathrm{m}^{-2}$ flux associated with the under-ice bloom in 1994 represented $23 \%$ of the estimated annual primary production of $59 \mathrm{~g} \mathrm{C} \mathrm{m}^{-2}$ in Barrow Strait (Welch et al. 1992). We conclude that, in some years, the particle flux generated by an under-ice phytoplankton bloom represents a net and significant addition to the annual vertical flux of particulate carbon.

\section{Trophic mediation of particulate carbon fluxes under sea ice in spring and early summer}

Given their abundance and the ability of some species to feed at or near the ice-water interface in spring, copepods can mediate the under-ice flux of particulate matter (Wassmann \& Slagstad 1993), either accelerating it by the production of fast-sinking faecal pellets (Andreassen et al. 1996) or slowing it down by the ingestion and break-down of sinking aggregates (Sasaki et al. 1988, Green \& Dagg 1997) and faecal pellets (Sasaki et al. 1988, Lampitt et al. 1990, González \& Smetacek 1994). In the ocean, the contribution of faecal pellets to the overall carbon flux may vary from $<1$ to $99 \%$ depending on season and region (see Lampitt et al. 1990 for review), with a majority of estimates falling within the $<1$ to $40 \%$ range (e.g. Bathmann et al. 1987, Sasaki et al. 1988, Lane et al. 1994). Consistent with this range, the estimated fraction of the POC flux represented by faecal pellets in icecovered Barrow Strait in 1994 and 1995 was usually $<10 \%$, with peak values of 10 to $37 \%$. In 1994, the faecal fraction of the POC flux was minimum $(<5 \%)$ during the release of ice algae and the under-ice bloom, and maximum (up to $37 \%$ at $30 \mathrm{~m}$ ) during the interval of reduced flux between the 2 events (Fig. 8G). This is consistent with the interpretation that zooplankton herbivores were swamped by the abrupt flux of ice algae and the under-ice bloom. Because of the $16 \mathrm{~d}$ interruption of trap deployment starting in mid-June, our sampling resolution in 1995 may have been too coarse to detect an increase in the fraction of the flux intercepted during the interval between the release of ice algae and the under-ice bloom (Fig. 8H).

The faecal fraction of the POC flux (for example, on average $6.9 \%$ in 1994 and $6.1 \%$ in 1995 at $90 \mathrm{~m}$ : Table 1) largely underestimates the actual fraction of the potential microalgal flux intercepted by grazers for 3 reasons. First, faeces represent only the non-assimilated part of the biomass consumed by zooplankton; assimilation efficiencies of Arctic herbivorous copepods feeding on phytoplankton are high, ranging from 53 to $90 \%$ (Conover 1966). Second, not all the faecal material can be identified as such in the samples. Third, the fraction of the faecal matter produced in the surface layer that actually reaches depth may be small because of pellet degradation and re-suspension (e.g. $<5 \%$, Bathmann et al. 1987; <40\%, Lane et al. 1994; 2 to $6 \%$, González et al. 1994). At the low temperatures prevailing under sea ice $\left(-1.6\right.$ to $\left.-1.8^{\circ} \mathrm{C}\right)$, microbial degradation may be weak (Lampitt et al. 1990), but pellet recycling through coprophagy and coprorhexy by both calanoid and cyclopoid copepods could be important (e.g. Lampitt et al. 1990, González \& Smetacek 1994). Assuming an assimilation efficiency 
of $60 \%$ (Welch et al. 1992), that $70 \%$ of the faecal material was recognised in the sample, and that $10 \%$ of the faecal material actually reached $90 \mathrm{~m}$, the estimated average fraction of the potential flux of microalgae intercepted by grazers would be as high as $55 \%$ $(\mathrm{SD}=17 \%)$ for 1994 and $52 \%(\mathrm{SD}=18 \%)$ for 1995 .

Although comparable data on the faecal flux are not available for 1992, several lines of evidence indicate that, in that year, most of the biomass of ice algae released into the water column was intercepted by pelagic grazers, in particular Pseudocalanus acuspes. This species, which was on average 8- and 120-fold more abundant in 1992 than in 1994 and 1995, respectively (Fortier 1999), has been shown to graze at or near the ice-water interface (Conover et al. 1986b, Runge et al. 1991, Hattori \& Saito 1997). In May 1992, the chl a:chloropigment ratio was high in the ice but remarkably low in the water column, even in the 0 to $1 \mathrm{~m}$ layer, confirming intense grazing immediately under the ice-water interface. Using a carbon budget model based on pigment concentrations in the ice, the water column, and the sediment traps, Michel et al. (1996) estimated that 60 to $70 \%$ of the exported carbon was in the form of faecal matter in 1992. Direct measurements of $P$. acuspes grazing rates between the 0.5 and $2.5 \mathrm{~m}$ traps during their peak abundance on 21 May suggest that this species intercepted $81 \%$ of the flux (H. Hattori pers. comm.). The impact of $P$. acuspes grazing is also supported by the strong negative correlation between the biomass of $P$. acuspes and the chl $a$ : chloropigment ratio in the water column $(\mathrm{r}=-0.87, \mathrm{n}=$ $13, \mathrm{p}<0.01)$ and in the traps $(\mathrm{r} \approx-0.84$ : Table 3$)$ over the 1992 sampling period. Finally, egg production by $P$. acuspes, a species that requires an external source of food to reproduce (Conover \& Huntley 1991), increased drastically in May 1992 (Fortier 1999), confirming intense grazing of released ice algae by this copepod. It is likely that most of the faecal material was recycled several times by the unusually abundant population of $P$. acuspes and the exceptionally large biomass of calanoid copepods that prevailed during that year (Fig. 4). Hence, relative to 1994 and 1995, intense grazing and coprorhexy in 1992 should have favoured the retention of biogenic carbon in the pelagic food web and its recycling in the upper water column, at the expense of its export to depth.

\section{Climate, climate change and the export of microalgae production to the pelagic food web and to depth in ice-covered seas}

By controlling the integrity of the ice matrix and the under-ice irradiance, snow thickness and snowmelt are the primary factors determining the production and release of ice algae and the under-ice production of phytoplankton in spring (Legendre et al. 1981, Fukuchi et al. 1989, Welch \& Bergmann 1989, Cota et al. 1991, Strass \& Nöthig 1996, this study). In the present study, the 3 yr comparison illustrates how meteorological events, through the control of snow thickness and under-ice irradiance, dictate interannual variations in the timing and intensity of the flux of particulate matter under first-year sea ice. In Arctic seas, the production period is short, so that the timing between the production of microalgae and the cycle of zooplankton abundance will affect the fraction of the total biogenic carbon that is exported from the surface layer to depth (Peinert et al. 1989, Legendre et al. 1992). Our results indicate that in years when snow melt is late and the density of calanoids (especially Pseudocalanus acuspes) is high, herbivorous zooplankton may intercept the bulk (up to $75 \%$ ) of the small flux of microalgae released from the ice (see also Michel et al. 1996). In such years, the abundant planktonic grazers may actually control microalgal production in the water column and delay the onset of the phytoplankton bloom. We suspect that, under these conditions, most of the faecal pellets will be recycled in the water column by the food-limited grazers. In contrast in years of early snow melt, zooplankton herbivores may be swamped by the sudden release of ice algae and the intense under-ice phytoplankton bloom, with most of the microalgae sinking to depth intact.

The meteorological conditions that affected snow cover dynamics, under-ice irradiance, microalgal production and, ultimately, particle fluxes, varied remarkably over the 3 yr studied (Fig. 2). A question that arises is whether the observed interannual variability was representative of the long-term range in climatic conditions. Meteorological records for Resolute Bay are available starting in 1950 . With reference to the period 1950 to 1995, the final melt of the snow cover was relatively late in 1992 (8 out of $45 \mathrm{yr}$ with snowmelt as late or later), early in 1994 (3 out of 45 yr with same or earlier date of snowmelt) and intermediate in 1995 (Fig. 10A). The rain in late May 1994 was the earliest on record and the only significant rain event that occurred before 1 June since 1950 (Fig. 10B). The heatwave of 1 to 9 June 1995 was exceptionally early and intense, as comparable air temperature $\left(>8^{\circ} \mathrm{C}\right)$ occurred only once prior to 15 June in the period 1950 to 1994 (Fig. 10C). Hence, while the persisting ice cover of 1992 represented a relatively frequent situation, the early rain of 1994 and the heatwave of 1995 were unusual occurrences.

Precipitation scenarios from the general circulation model (GCM) of the Canadian Centre for Climate Modelling and Analysis (CCC92) for the Canadian Arctic predict an increase of 3 to $5^{\circ} \mathrm{C}$ in air temperature 

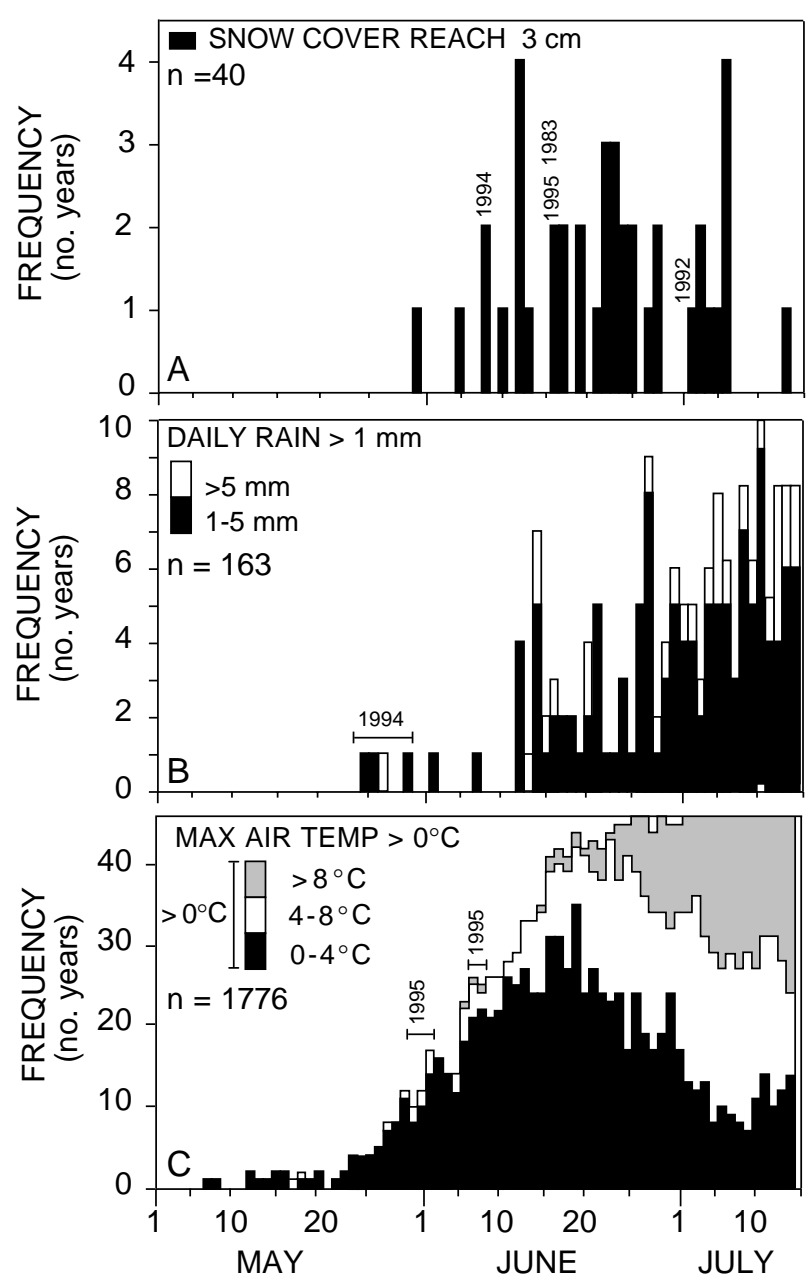

Fig. 10. Timing and frequency of meteorological events in spring and early summer at Resolute Bay over the period 1950 to 1995. (A) Number of years when the final melt of the snow cover (i.e. thickness decreased to $<3 \mathrm{~cm}$ ) occurred on a given date. (B) Number of years when 1 to $5 \mathrm{~mm}$ and/or $>5 \mathrm{~mm}$ of rain fell on a given date. (C) Number of years when maximum air temperature reached 0 to 4,4 to 8 , or $>8^{\circ} \mathrm{C}$ on a given date. Dates of final snowmelt for 1992, 1994 and 1995 are indicated in (A), rain event of late May 1994 in (B), and heatwave of early June 1995 in (C)

in spring and a general increase in precipitation of between 0 and $25 \%$ for a doubling of atmospheric $\mathrm{CO}_{2}$ (e.g. Maxwell 1997). Thus, although GCMs are not very precise at the regional scale (e.g. Cattle \& Crossley 1996), the frequency of early rain and heatwaves is expected to increase in the Canadian Archipelago, so that snowmelt may occur weeks earlier than at present (Woo 1990). Under these conditions, our observations in Barrow Strait indicate that abrupt releases of ice algae and under-ice phytoplankton blooms, with the accompanying pulses in the vertical chloropigment and POC fluxes, will become more frequent in areas covered by seasonal sea ice. The fraction of the microalgal production that is exported to the pelagic food web, however, also depends to a large extent on the composition of the herbivore assemblage. For example, a higher abundance of Pseudocalanus acuspes in 1994 and 1995 could have resulted in the channelling of a much larger fraction of the microalgal production to the pelagic food web, despite the unusual seasonal pattern of particulate flux. Although well documented (Conover et al. 1991, Fortier 1999), large interannual variations in the abundance of $P$. acuspes, a key species in the interception of the particle flux, remain poorly understood. Elucidating the ecological causes of such variations would contribute to improved modelling and prediction of vertical and trophic carbon fluxes in a changing Arctic.

Acknowledgements. This project was part of the SaromaResolute Study (SARES), a joint Canada-Japan research program on the biological productivity of Arctic and subarctic seas, funded in Canada by the Canada-Japan Science and Technology Fund of the Ministry of External Affairs and Trade Canada, the Natural Sciences and Engineering Research Council of Canada and the Fonds FCAR du Québec. M.F. benefited from scholarships from the Fonds FCAR du Québec and the Northern Scientific Training Program (NSTP) of the Ministry of Indian and Northern Affairs Canada. Logistics in the Arctic was provided by the Polar Continental Shelf Project of the Department of Natural Resources Canada. Special thanks to G. Bergeron, B. Leblanc, L. Létourneau, L. Michaud, A. Potvin and M.A. Rémillard for help in the field and/or the laboratory. Contribution to the program of GIROQ (Groupe Interuniversitaire de Recherches Océanographiques du Québec).

\section{LITERATURE CITED}

Andreassen I, Nöthig EM, Wassmann P (1996) Vertical particle flux on the shelf off northern Spitsbergen, Norway. Mar Ecol Prog Ser 137:215-228

Anning JL (1989) The development and decline of the epontic algal community in Barrow Strait, N.W.T. MSc thesis, University of Guelph

Apollonio S (1965) Chlorophyll in Arctic sea ice. Arctic 18: $118-122$

Atkinson EG, Wacasey JW (1987) Sedimentation in Arctic Canada: particulate organic carbon flux to a shallow marine benthic community in Frobisher Bay. Polar Biol 8:3-7

Bathmann UV, Noji TT, Voss M, Peinert R (1987) Copepod fecal pellets: abundance, sedimentation and content at a permanent station in the Norwegian Sea in May/June 1986. Mar Ecol Prog Ser 38:45-51

Bender M, Ducklow H, Kiddon J, Marra J, Martin J (1992) The carbon balance during the 1989 spring bloom in the North Atlantic Ocean, $47^{\circ} \mathrm{N}, 20^{\circ} \mathrm{W}$. Deep-Sea Res Part I 39:1707-1725

Boyd P, Newton P (1995) Evidence of the potential of planktonic community structure on the interannual variability of particulate organic carbon flux. Deep-Sea Res 42:619-639

Carey AG (1987) Particle flux beneath fast ice in the shallow southwestern Beaufort Sea, Arctic Ocean. Mar Ecol Prog Ser 40:247-257

Cattle H, Crossley J (1996) Modelling Arctic climate change. 
In: Wadhams P, Dowdeswell JA, Schofield AN (eds) The Arctic and environmental change. Gordon \& Breach, Amsterdam, p 1-13

Conover RJ (1966) Assimilation of organic matter by zooplankton. Limnol Oceanogr 11:338-345

Conover RJ, Huntley M (1991) Copepods in ice-covered seas. Distribution, adaptations to seasonally limited food, metabolism, growth patterns and life strategies in polar seas. J Mar Syst 2:1-41

Conover RJ, Durvasula R, Roy S, Wang R (1986a) Probable loss of chlorophyll-derived pigments during passage through the gut of zooplankton, and some of the consequences. Limnol Oceanogr 31:878-887

Conover RJ, Herman AW, Prinsenberg SJ, Harris LR (1986b) Distribution of and feeding by the copepod Pseudocalanus under fast ice during the Arctic spring. Science 232: 1245-1247

Conover RJ, Harris LR, Bedo AW (1991) Copepods in cold oligotrophic waters. How do they cope? Bull Plankton Soc Jpn Spec Vol: 177-199

Conover RJ, Mumm N, Bruecker P, MacKenzie S (1999) Sources of urea in arctic seas: seasonal fast ice? Mar Ecol Prog Ser 179:55-69

Cota GF, Legendre L, Gosselin M, Ingram RG (1991) Ecology of bottom ice algae. I. Environmental controls and variability. J Mar Syst 2:257-277

Dagg MJ, Walser WE Jr (1987) Ingestion, gut passage, and egestion by the copepod Neocalanus plumchrus in the laboratory and in the subarctic Pacific Ocean. Limnol Oceanogr 32:178-188

Emerson S, Quay P, Karl D, Winn C, Tupas L, Landry M (1997) Experimental determination of the organic carbon flux from open-ocean surface water. Nature (Lond) 389:951-954

Fortier L, Le Fèvre J, Legendre L (1994) Export of biogenic carbon to fish and to the deep ocean: the role of large planktonic microphages. J Plankton Res 16:809-839

Fortier L, Fortier M, Demers S (1995) Zooplankton and larval fish community development: comparative study under first-year sea ice at low and high latitudes in the Arctic. Proc Natl Inst Polar Res (NIPR) Symp Polar Biol 8:11-19

Fortier M (1999) Climatic and biological forcing of the vertical flux of biogenic carbon under the first-year ice in the Canadian Arctic in spring. PhD thesis, Université Laval, Québec, Canada

Fukuchi M, Watanabe K, Tanimura A, Hoshiai T, Sasaki H, Satoh H, Yamagushi Y (1989) A phytoplankton bloom under sea ice recorded with a moored system in Lagoon Saroma Ko, Hokkaido, Japan. Proc Natl Inst Polar Res (NIPR) Symp Polar Biol 2:9-15

González HE, Smetacek V (1994) The possible role of the cyclopoid copepod Oithona similis in retarding the vertical flux of zooplankton faecal material. Mar Ecol Prog Ser 113: $133-146$

González HE, González SR, Brummer GJA (1994) Short-term sedimentation pattern of zooplankton faeces and microplankton at a permanent station in the Bjørnafjorden (Norway) during April-May 1992. Mar Ecol Prog Ser 105:31-45

Grebmeier JM, Barry JP (1991) The influence of oceanographic processes on pelagic-benthic coupling in polar regions: a benthic perspective. J Mar Syst 2:495-518

Green EP, Dagg MJ (1997) Mesozooplankton associations with medium to large marine snow aggregates in the northern Gulf of Mexico. J Plankton Res 19:435-447

Harrison WG, Cota GF (1991) Primary production in polar waters: relation to nutrient availability. Polar Res 10: 87-104

Harrison WG, Platt T (1986) Photosynthesis-irradiance rela- tionships in polar and temperate phytoplankton populations. Polar Biol 5:153-164

Harrison WG, Platt T, Irwin B (1982) Primary production and nutrient assimilation by natural phytoplankton populations of the eastern Canadian Arctic. Can J Fish Aquat Sci 39:335-345

Hattori H, Saito H (1997) Diel changes in vertical distribution and feeding activity of copepods in ice-covered Resolute Passage, Canadian Arctic, in spring 1992. J Mar Syst 11: 205-219

Horner RA (1985) Sea ice biota. CRC Press, Boca Raton, FL

Horner RA, Ackley SF, Dieckmann GS, Gulliksen B and 6 others (1992) Ecology of sea ice biota. 1. Habitat, terminology, and methodology. Polar Biol 12:417-427

Lampitt RS, Noji T, von Bodungen B (1990) What happens to zooplankton faecal pellets? Implications for material flux. Mar Biol 104:15-23

Lane PVZ, Smith SL, Urban JL, Biscaye PE (1994) Carbon flux and recycling associated with zooplanktonic fecal pellets on the shelf of the Middle Atlantic Bight. Deep-Sea Res 41: $437-457$

Legendre L, Ingram RG, Poulin M (1981) Physical control of phytoplankton production under sea ice (Manitounuk Sound, Hudson Bay). Can J Fish Aquat Sci 38:1385-1392

Legendre L, Ackley SF, Dieckmann GS, Gulliksen B and 6 others (1992) Ecology of sea ice biota. 2. Global significance. Polar Biol 12:429-444

Maxwell B (1997) Responding to global climate change in Canada's Arctic. Canada country study, Vol 2, Climate impacts and adaptation. Atmospheric Environment Service, Downsview, Ontario

Michel C, Legendre L, Ingram RG, Gosselin M, Levasseur M (1996) Carbon budget of sea-ice algae in spring - evidence of a significant transfer to zooplankton grazers. J Geophys Res 101:18345-18360

Olesen M, Lundsgaard C (1995) Seasonal sedimentation of autochthonous material from the euphotic zone of a coastal system. Estuar Coast Shelf Sci 41:475-490

Pasternak AF, Drits AV (1988) Possible degradation of chlorophyll-derived pigments during gut passage of herbivorous copepods. Mar Ecol Prog Ser 49:187-190

Peinert R, von Bodungen B, Smetacek V (1989) Food web structure and loss rates. In: Berger W, Smetacek V, Wefer G (eds) Productivity in the ocean: present and past. Wiley, New York, p 34-48

Prinsenberg SJ, Bennett EB (1987) Mixing and transport in Barrow Strait, the central part of the Northwest Passage. Cont Shelf Res 7:913-935

Runge JA, Therriault JC, Legendre L, Ingram RG, Demers S (1991) Coupling between ice microalgal productivity and the pelagic, metazoan food web in southeastern Hudson Bay: a synthesis of results. Polar Res 10:325-338

Rysgaard S, Nielsen TG, Hansen B W (1999) Seasonal variation in nutrients, pelagic primary production and grazing in a high-Arctic coastal marine ecosystem, Young Sound, Northeast Greenland. Mar Ecol Prog Ser 179:13-25

Sasaki H, Hattori H, Nishizawa S (1988) Downward flux of particulate organic matter and vertical distribution of calanoid copepods in the Oyashio Water in summer. DeepSea Res 35:505-515

Smith REH, Anning J, Clement P, Cota G (1988) Abundance and production of ice algae in Resolute Passage, Canadian Arctic. Mar Ecol Prog Ser 48:251-263

Strass VH, Nöthig EV (1996) Seasonal shifts in ice edge phytoplankton blooms in the Barents Sea related to the water column stability. Polar Biol 16:409-422

Tremblay C, Runge JA, Legendre L (1989) Grazing and sedi- 
mentation of ice algae during and immediately after a bloom at the ice-water interface. Mar Ecol Prog Ser 56: 291-300

Uye SI (1982) Length-weight relationships of important zooplankton from the island Sea of Japan. J Oceanogr Soc Jpn 38:149-158

Wadhams P (1990) Sea ice and economic development in the Arctic Ocean - a glaciologist's experience. In: Arctic technology and economy. Present situation, problems and future issues. Bureau Veritas, Paris, France, p 1-23

Wassmann P, Slagstad D (1993) Seasonal and annual dynamics of particle flux in the Barents Sea: a model approach. Polar Biol 13:363-372

Editorial responsibility: Otto Kinne (Editor),

Oldendorf/Luhe, Germany
Wassmann P, Svendsen H, Heck A, Reigstad M (1996) Selected aspect of the physical oceanography and particle fluxes in fjords of northern Norway. J Mar Syst 8:53-71

Welch HE, Bergmann MA (1989) Seasonal development of ice algae and its prediction from environmental factors near Resolute, N.W.T., Canada. Can J Fish Aquat Sci 46: 1793-1804

Welch HE, Bergmann MA, Siferd TD, Martin KA, Curtis MF, Crawford RE, Conover RJ, Hop H (1992) Energy flow through the marine ecosystem of the Lancaster Sound region, Arctic Canada. Arctic 45:343-357

Woo MK (1990) Consequences of climatic change for hydrology in permafrost zones. J Cold Reg Engng 4:15-20

Submitted: May 15, 2000; Accepted: February 15, 2001

Proofs received from author(s): January 3, 2002 